\title{
RELATED FACTORS OF RESPONSE TIME IN HANDLING HEAD INJURY IN EMERGENCY UNIT OF PROF.DR.H.M.ANWAR MAKKATUTU BANTAENG GENERAL HOSPITAL
}

\author{
Satrial Mudatsir ${ }^{1}$, Moh. Syafar Sangkala ${ }^{2}$, Andina Setyawati ${ }^{3}$ \\ ${ }_{1,2,3}$ Program Studi Ilmu Keperawatan, Universitas Hasanuddin, Makassar \\ e-mail :rial_mudatsir@ymail.com
}

\begin{abstract}
Introduction: The mechanisms of nurse response time in handling head injury patients has an important role on the safety and viability of patients in reference to the rules of "safety and time saving is life saving". The purpose of the study: This study aims to identify factors that related to the response time in handling head injury patient in emergency department (ED) and to determine the most related factor to the response time. Method: This study was an observation design and using cross sectional approach. A total sample of 32 emergency department nurses participated for this study, in references to the inclision and exclusion criteria. The data were analyzed by using chi-square, Fisher's extract test and logistic regression. Result: This study found that there were statistical significance between respon time and level of education $(\mathrm{p}=$ 0.006), duration of working $(p=0.005)$, medical emergency training $(p=0.001)$, the emergency department facilities $(p=0.008)$ and the level of the patient acute condition $(p=0.006)$. Among the factors, it was found that facilities most related factor to the respon time $(O R=6.945)$. Conclusion and suggestion: It is concluded that there is a relationship between respon time and education level, work duration of nurses, medical emergency training, Emergency facilities and the patient acute condition in handling head injury patients and facilities are the factors that most related to the response time handling head injury. It is suggested to the hospital to complete the emergency room facilities because the facilities affects the response time handling head injury patients.
\end{abstract}

Keywords: That relates factors, the response time, handling head injury patients

\section{PENDAHULUAN}

Cedera kepala merupakan salah satu masalah kesehatan yang menjadi penyebab utama tingginya angka kematian pada populasi manusia di usia produktif di bawah 45 tahun. Cedera kepala dapat menyebabkan gangguan fisik dan mental yang kompleks, baik yang bersifat sementara ataupun menetap seperti defisit kognitif, psikis, intelektual, serta gangguan fungsi fisiologis lainnya. (Iskandar, 2004).

Insiden cedera kepala secara global terus mengalami peningkatan seiring bertambahnya peningkatan penggunaan kendaraan bermotor. Insiden cedera kepala di Eropa pada tahun 2010 adalah 500 per 100.000 populasi (Lingsma, 2010) sedangkan menurut Shiroma (2010), terdapat lebih dari 1,1 juta orang Amerika Serikat menderita cedera kepala setiap tahunnya.

Peningkatan insiden cedera kepala tidak hanya terjadi di kota-kota besar tetapi juga terjadi di kabupaten kota. Data yang diperoleh dari bagian Instalasi Rekam Medik RSUD Prof. Dr.H.M.Anwar Makkatutu Kabupaten Bantaeng bahwa terjadi peningkatan jumlah pasien cedera kepala disetiap tahunnya. Tahun 2010 pasien cedera kepala sekitar 386 pasien dan tahun 2011 tercatat sekitar 437 orang, jumlah ini mengalami peningkatan pada tahun 2012 sebanyak 612 pasien (Rekam medik, 2013).

Instalasi Rawat Darurat (IRD) sebagai gerbang utama penanganan 
kasus gawat darurat di rumah sakit berperan penting dalam upaya penyelamatan hidup khususnya penderita cedera kepala. Penanganan cedera kepala harus cepat, tepat dan cermat serta sesuai dengan prosedur yang ada, selain itu prinsip umum penatalaksanaan cedera kepala juga menjadi acuan penting mencegah kematian dan kecacatan, misalnya tatalaksana Airway, Breathing, Circulation, Disability dan Exposure (ABCDE), mengobservasi tanda-tanda vital, mempertahankan oksigenasi yang adekuat, menilai dan memperbaiki gangguan koagulasi, mempertahankan hemostatis dan gula darah, nutrisi yang adekuat, mempertahankan $\mathrm{PaCO} 2$ 35$45 \mathrm{mmHg}$, dan lain-lain (Yulius, 2010).

Berdasarkan data dan teori yang telah dikemukakan, maka peneliti tertarik melakukan penelitian tentang "faktor-faktor yang berhubungan dengan waktu tanggap penanganan pasien cedera kepala di IRD RSUD. Prof.Dr.H.M. Anwar Makkatutu Kabupaten Bantaeng”.

\section{BAHAN DAN METODE}

Bentuk penelitian yang digunakan adalah Kuantitatif dengan metode observasional: Cross Sectional Study. Peneliti mengobservasi hubungan antara variabel Independen atau variabel bebas dengan variabel dependen atau variabel tergantung (Sugiyono, 2012). Lokasi penelitian di IRD RSUD. Prof. Dr.H.M. Anwar Makkatutu Kabupaten Bantaeng dan waktu penelitian pada tanggal 15 Juli sampai dengan 31 Agustus tahun 2013.

Populasi dalam penelitian adalah semua perawat yang bertugas di IRD RSUD. Prof. Dr.H.M. Anwar Makkatutu Kabupaten Bantaeng sebanyak 34 orang. Purposive sampling digunakan dalam memilih Sampel sehingga perawat yang memenuhi kriteria inklusi adalah 32 orang sesuai kriteria: perawat yang bertugas di IRD RSUD. Prof. Dr. H.M. Anwar Makkatutu Kabupaten Bantaeng dan bersedia menjadi responden, sedangkan kriteria eksklusi yaitu perawat yang bertugas di IRD tapi sedang menjalani cuti, masih berstatus magang dan perawat yang menjabat sebagai kepala ruangan dan perawat administratif.

Data yang diperoleh saat penelitian diolah dengan bantuan software pengolahan data dan diuji menggunakan uji Chi-Square dengan tingkat kepercayaan $\mathrm{P}=<0,05$, dalam analisis juga dilampirkan nilai Phi untuk mengetahui seberapa besar kekuatan hubungan dari setiap variabel yang dihubungkan. Analisa multivariat dilakukan terhadap variabel yang memiliki tingkat kepercayaan $\mathrm{P}=$ $<0,25$ dan dengan Logistik Regresi akan diketahui variabel yang paling berhubungan dengan waktu tanggap penanganan pasien cedera kepala.

\section{HASIL DAN PEMBAHASAN}

Hubungan Tingkat Pendidikan dengan Waktu Tanggap Penanganan Pasien Cedera Kepala. Hasil uji ChiSquare diperoleh nilai $\mathrm{p}=0,006$ yang berarti ada hubungan tingkat pendidikan dengan waktu tanggap penanganan pasien cedera kepala, kemudian diperoleh nilai $P h i=0,511$ yang berarti bahwa tingkat pendidikan dan waktu tanggap penanganan pasien cedera kepala memiliki hubungan yang kuat, hal ini menunjukkan bahwa semakin tinggi tingkat pendidikan maka akan semakin baik pula waktu tanggap dalam menangani pasien cedera kepala. 


\begin{tabular}{ccccccccc}
\hline \multirow{2}{*}{$\begin{array}{c}\text { Tingkat } \\
\text { Pendidikan }\end{array}$} & \multicolumn{9}{c}{ Waktu Tanggap Cedera Kepala } & \multirow{2}{*}{ P Value } & \multirow{2}{*}{ Phi } \\
\cline { 2 - 6 } & $\mathrm{n}$ & $\%$ & $\mathrm{n}$ & $\%$ & $\mathrm{n}$ & $\%$ & & \\
\hline D3 & 17 & 53.1 & 9 & 28.1 & 26 & 81.2 & \multirow{2}{*}{0.0006} & \multirow{2}{*}{0,511} \\
\hline S1+Ners & 0 & 0 & 6 & 18.8 & 6 & 18.8 & & \\
\hline Jumlah & 17 & 53.1 & 15 & 46.9 & 32 & 100 & & \\
\hline
\end{tabular}

Tabel 1. Distribusi Hubungan Tingkat pendidikan dengan Waktu Tanggap Penanganan Pasien Cedera Kepala $(\mathrm{n}=32)$

Pendidikan merupakan salah satu unsur yang berhubungan dengan perilaku asertif seseorang. Rendahnya tingkat pendidikan seorang perawat akan mempengaruhi perilaku serta kemampuannya dalam mengambil keputusan, pengembangan kreatifitas dan pemecahan masalah khususnya terhadap penanganan pasien yang membutuhkan tindakan atau pertolongan segera (Nursalam, 2013).

Hasil penelitian ini sejalan dengan penelitian yang dilakukan oleh Hafizurrachman (2011) yang meneliti tentang faktor yang mempengaruhi kinerja perawat dalam menjalankan kebijakan keperawatan di salah satu rumah sakit umum daerah di Yogyakarta, dengan sampel sebanyak 250 orang perawat dan menyatakan bahwa tingkat pendidikan memberikan pengaruh yang besar terhadap pelayanan yang diberikan oleh perawat, khususnya mereka yang bekerja di unit-unit yang membutuhkan penanganan pasien yang lebih cepat dan tepat tentunya. Penelitian yang dilakukannya menemukan hubungan yang kuat antara tingkat pendidikan dengan ketepatan waktu tanggap terhadap penanganan pasien., namun ini berbanding terbalik dengan penelitian yang dilakukan oleh Awases (2006), yang meneliti tentang faktorfaktor yang berhubungan dengan kinerja professional perawat di Namibia pada 147 orang perawat sebagai responden dan menemukan tidak ada hubungan antara tingkat pendidikan seorang perawat dengan waktu tanggap yang dilakukan saat memberikan tindakan kepada pasien.

Responden yang berasal dari lulusan S1+Ners yaitu (18,8\%) semuanya memiliki waktu tanggap yang baik, hal ini disebabkan tingginya tingkat pendidikan juga akan mempengaruhi pengetahuan perawat dalam menangani pasien yang berkunjung ke IRD khususnya penderita cedera kepala, selain itu beberapa dari perawat juga telah lama bekerja di IRD sehingga mereka jauh lebih tanggap dibanding yang lain.

Berbeda dengan lulusan diploma keperawatan (D3), peneliti menemukan bahwa lebih dari setengah jumlah responden yaitu $(53,1 \%)$ memiliki waktu tanggap yang buruk dikarenakan kurangnya pengetahuan dalam menangani pasien cedera kepala karena kebanyakan dari mereka baru bekerja di IRD dan belum mengikuti pelatihan kegawatdaruratan, sehingga kebanyakan dari mereka selalu menunggu petunjuk dari dokter jaga dan instruksi dari seniornya, hal ini menyebabkan molornya waktu tanggap penanganan terhadap pasien cedera kepala yang datang ke IRD, sedangkan mereka yang masih D3 keperawatan $(28,1 \%)$ sudah memiliki waktu tanggap yang baik.

Hal ini terjadi karena mereka lebih banyak mengetahui tindakan yang bisa segera dilakukan untuk menangani pasien cedera kepala yang datang ke IRD karena telah mengikuti pelatihan kegawatdaruratan, serta mayoritas dari D3 yang memiliki waktu tanggap yang baik telah lama bekerja di IRD atau masa kerja mereka kebanyakan sudah lebih dari

5 tahun yang menyebabkan waktu tanggap mereka lebih baik atau kurang dari 5 menit setelah kedatangan 
pasien di IRD.

Hubungan Lama Kerja Perawat di IRD dengan Waktu Tanggap Penanganan Pasien Cedera Kepala.

Hasil uji Chi-Square diperoleh nilai $\mathrm{p}=0,005$ yang menunjukkan ada hubungan lama kerja perawat di IRD dengan waktu tanggap

penanganan cedera kepala, kemudian diperoleh nilai $P h i=0,566$ yang berarti bahwa lama kerja perawat di IRD memiliki hubungan yang sangat kuat dengan waktu tanggap penanganan pasien cedera kepala, hal ini menunjukkan bahwa semakin lama seorang perawat bekerja di IRD maka akan semakin baik pula waktu tanggapnya terhadap penanganan pasien cedera kepala.

\begin{tabular}{ccccccccc}
\hline \multirow{2}{*}{$\begin{array}{c}\text { Lama Kerja } \\
\text { Perawat }\end{array}$} & \multicolumn{9}{c}{ Waktu Tanggap Cedera Kepala } & & \multirow{2}{*}{ P Value } & \multirow{2}{*}{ Phi } \\
\cline { 2 - 6 } & $\mathrm{n}$ & $\%$ & $\mathrm{n}$ & $\%$ & $\mathrm{n}$ & $\%$ & & \\
\hline Baru & 15 & 46.9 & 5 & 15.6 & 20 & 62.5 & \multirow{2}{*}{0.0005} & \multirow{2}{*}{0.566} \\
\hline Lama & 2 & 6.2 & 10 & 31.3 & 12 & 37.5 & & \\
\hline Jumlah & 17 & 53.1 & 15 & 46.9 & 32 & 100 & & \\
\hline
\end{tabular}

Tabel 2. Distribusi Hubungan Lama kerja Perawat dengan Waktu Tanggap Penanganan Pasien Cedera Kepala $(\mathrm{n}=32)$

Keadaan tersebut diatas sesuai dengan teori yang menyatakan bahwa lama masa kerja perawat berpengaruh terhadap pengalamannya dalam menangani masalah kegawatdaruratan khususnya pasien cedera kepala, sedangkan mereka yang masih baru dengan masa kerja yang kurang memungkinkan keterampilan dalam penanganan pasien belum cukup terlatih. (Meltzer, 2004).

Hasil dari penelitian ini sejalan dengan penelitian yang dilakukan oleh Kasmarani (2012) yang meneliti tentang pengaruh beban kerja fisik dan mental terhadap stress kerja pada perawat di IGD RSUD Cianjur pada 26 orang perawat sebagai responden, hasilnya menunjukkan ada hubungan antara lama kerja seorang perawat dengan stress kerja yang dialami dan berdampak pada waktu tanggap dalam melayani pasien.

Hasil penelitian menunjukkan bahwa kurang dari setengah jumlah responden $(46,9 \%)$ yang baru bekerja di IRD dengan masa kerja dibawah 5 tahun memiliki waktu tanggap yang buruk, hal ini dikarenakan kurangnya pengalaman mereka terhadap penanganan pasien cedera kepala khususnya pasien-pasien dengan tingkat kegawatan sedang-berat. Selain itu terdapat $(15,6 \%)$ atau kurang dari seperempat jumlah responden yang masih tergolong baru bekerja di IRD tetapi mereka memiliki waktu tanggap yang baik, hal ini disebabkan mereka lebih cepat dalam merespon pasien cedera kepala yang masuk ke IRD karena telah mengikuti pelatihan kegawatdaruratan, sehingga ketepatan waktu tanggap yang dimiliki sesuai dengan standar yang ditentukan oleh Departemen Kesehatan (DepKes) yaitu kurang dari 5 menit. Berbeda dengan responden yang telah lama bekerja di IRD (31,3\%) dengan masa kerja lebih dari 5 tahun, menunjukkan bahwa mereka memiliki waktu tanggap yang baik, hal ini disebabkan oleh banyaknya pengalaman atau seringnya mereka berhadapan dengan kasuskasus yang berat khususnya pasien cedera kepala, akan tetapi terdapat $(6,2 \%)$ atau kurang dari seperempat jumlah responden yang sudah lama bekerja di IRD tetapi memiliki waktu tanggap yang buruk

atau lebih dari 5 menit, hal ini disebabkan karena lambatnya mereka dalam memberikan respon saat pasien 
tiba di depan pintu IRD serta pasien yang mereka tangani berada pada tingkat kegawatan ringan sehingga mereka mengabaikan karena dianggap pasien tersebut tidak membutuhkan penanganan segera atau masih bisa ditunda sampai pasien lain selesai ditangani.

$\mathrm{Hubungan} \quad \mathrm{Pel}$ atihan Kegawatdaruratan dengan Waktu Tanggap Penanganan Pasien Cedera Kepala.

Hasil uji statistik diperoleh nilai $\mathrm{p}=0,001$ yang berarti bahwa ada hubungan Pelatihan kegawatdaruratan dengan waktu tanggap penanganan pasien cedera kepala, kemudian diperoleh nilai $\mathrm{Phi}=0,649$ yang menunjukkan bahwa pelatihan kegawatdaruratan memiliki kekuatan hubungan yang kuat dengan waktu tanggap penanganan pasien cedera kepala, hal ini menunjukkan bahwa seorang perawat yang pernah mengikuti pelatihan kegawatdaruratan maka akan semakin baik dalam menangani pasien cedera kepala khususnya terkait dengan waktu tanggap.

\begin{tabular}{ccccccccc}
\hline \multirow{2}{*}{$\begin{array}{c}\text { Pelatihan } \\
\text { Kegawatdaruratan }\end{array}$} & \multicolumn{6}{c}{ Waktu Tanggap Cedera Kepala } & \multirow{2}{*}{ P Value } & \multirow{2}{*}{ Phi } \\
\cline { 2 - 6 } & $\mathrm{n}$ & $\%$ & $\mathrm{n}$ & $\%$ & $\mathrm{n}$ & $\%$ & & \\
\hline Tidak Pernah Ikut & 12 & 37.5 & 1 & 3.1 & 13 & 40.6 & \multirow{2}{*}{0.001} & \multirow{2}{*}{0.649} \\
\hline Pernah Ikut & 5 & 15.6 & 14 & 43.8 & 19 & 59.4 & & \\
\hline Jumlah & 17 & 53.1 & 15 & 46.9 & 32 & 100 & & \\
\hline
\end{tabular}

Tabel 3. Distribusi Hubungan Pelatihan Kegawatdaruratan dengan Waktu Tanggap Penanganan Pasien Cedera Kepala $(n=32)$

Keadaan tersebut di atas sesuai dengan teori yang dijelaskan bahwa pelatihan memberikan dampak yang besar terhadap kemampuan seseorang dalam mengambil keputusan khususnya pada situasi kritis, misalnya dalam penanganan pasien cedera kepala. Peserta pelatihan akan dituntun untuk mampu secara teori dan juga dalam aplikasi sehingga memudahkan mereka dalam memberikan pelayanan di unit rawat darurat dalam kondisi apapun terhadap pasien dengan kasus yang mungkin berbeda-beda dalam satu waktu (Yayasan Ambulans Gawat Darurat, 2009).

Hasil penelitian sebelumnya yang dilakukan oleh Awases (2006) menunjukkan pelatihan kegawatdaruratan memiliki hubungan dengan waktu tanggap perawat dalam penanganan kasus cedera kepala di IRD, akan tetapi berbanding terbalik dengan penelitian yang dilakukan oleh Jus (2008) yang menyatakan tidak ada hubungan pelatihan kegawatdaruratan yang pernah diikuti oleh perawat dengan ketepatan waktu tanggap yang mereka miliki. Hal ini berdasarkan hasil penelitiannya yang membandingkan perawat yang pernah mengikuti pelatihan BTCLS, ATLS dan EKG Dasar dengan perawat yang tidak pernah mengikuti pelatihan tersebut, yang menunjukkan tidak ada perbedaan dari ketepatan waktu tanggap keduanya dalam menangani pasien serta tidak ada perbedaan keduanya dalam melakukan perawatan pasien cedera kepala yang masuk ke IRD.

Hasil penelitian terhadap 32 orang responden menunjukkan bahwa $(43,8 \%)$ atau kurang dari setengah jumlah responden yang pernah mengikuti pelatihan kegawatdaruratan telah memiliki waktu tanggap baik. Hal ini mungkin dikarenakan pelatihan yang mereka ikuti memberikan pengaruh yang besar terhadap keterampilan dan pengetahuan mereka dalam menangani pasien cedera kepala yang masuk ke IRD sehingga waktu tanggap mereka dalam penanganan 
kurang dari 5 menit atau sesuai dengan standar yang telah ditentukan oleh DepKes, akan tetapi terdapat $(15,6 \%)$ atau kurang dari seperempat jumlah responden yang pernah ikut pelatihan masih memiliki waktu tanggap yang buruk, hal ini dikarenakan banyak dari mereka yang pernah ikut pelatihan kegawatdaruratan tidak mampu mengimplementasikan pengetahuan dan keterampilan yang mereka dapatkan saat mengikuti pelatihan.

Responden yang tidak pernah mengikuti pelatihan sebanyak $(37,5 \%)$ semuanya memiliki waktu tanggap yang buruk. Hal ini karena pengetahuan dan keterampilan dalam penanganan pasien khususnya pasien cedera kepala yang masuk ke IRD masih sangat minim, akibat kurangnya motivasi dalam memperbaharui ilmu dan keterampilan yang mereka miliki sebelumnya yang seharusnya bisa didapatkan di tempat-tempat pelatihan selain dari ruang kuliah saat masih menempuh dunia pendidikan. Akan tetapi terdapat $(3,1 \%)$ responden yang memiliki waktu tanggap yang baik meskipun tidak pernah mengikuti pelatihan, hal ini dikarenakan sebenarnya responden tersebut sudah mengikuti pelatihan kegawatdaruratan sebelumya, akan tetapi sertifikat yang responden miliki sudah tidak berlaku lagi atau sudah kadaluarsa. Hal ini tidak mempengaruhi kualitas waktu tanggap yang responden miliki dalam menangani pasien cedera kepala, faktor lain yang menyebabkan responden tersebut tanggap dalam penanganan pasien cedera kepala karena masa kerjanya yang sudah lebih dari 5 tahun di IRD dan hal tersebut berpengaruh terhadap pengalamannya dalam menangani pasien cedera kepala.

Hubungan Fasilitas IRD dengan Waktu Tanggap Penanganan Pasien Cedera Kepala. Hasil uji statistik diperoleh nilai $\mathrm{p}=0,008$ yang berarti ada hubungan fasilitas IRD dengan waktu tanggap penanganan cedera kepala, kemudian diperoleh nilai $P h i=0,497$ yang menunjukkan bahwa fasilitas IRD memiliki kekuatan hubungan yang sedang dengan waktu tanggap penanganan pasien cedera kepala, hal ini berarti bahwa semakin lengkap fasilitas yang dibutuhkan dalam menanganai pasien maka akan semakin baik pula waktu tanggap penanganan pasien tersebut, begitupun sebaliknya jika fasilitas tidak tersedia maka akan memperlambat penanganan pasien tersebut.

Keadaan tersebut diatas sejalan dengan teori yang menyatakan bahwa ketersediaan fasilitas dalam suatu ruangan akan berpengaruh terhadap kinerja dari karyawan yang bekerja di tempat tersebut, sama halnya dengan ketersediaan fasilitas di ruang pelayanan di rumah sakit, jika fasilitas rumah sakit tersebut lengkap maka berdampak baik bagi pelayanan yang diberikan dengan catatan perawat atau tenaga kesehatan lain mampu mengoprasikan atau menggunakan fasilitas tersebut dengan baik dan benar (Hapsari,2008)

\begin{tabular}{|c|c|c|c|c|c|c|c|c|}
\hline \multirow{3}{*}{$\begin{array}{l}\text { Fasilitas } \\
\text { IRD }\end{array}$} & \multicolumn{6}{|c|}{ Waktu Tanggap Cedera Kepala } & \multirow{3}{*}{ P Value } & \multirow{3}{*}{ Phi } \\
\hline & \multicolumn{2}{|c|}{ Buruk } & \multicolumn{2}{|c|}{ Baik } & \multicolumn{2}{|c|}{ Total } & & \\
\hline & $\mathrm{n}$ & $\%$ & $\mathrm{n}$ & $\%$ & $\mathrm{n}$ & $\%$ & & \\
\hline $\begin{array}{c}\text { Tidak } \\
\text { Tersedia }\end{array}$ & 7 & 21.9 & 0 & 0 & 7 & 21.9 & \multirow[t]{2}{*}{0.008} & \multirow[t]{2}{*}{0.497} \\
\hline Tersedia & 10 & 31.3 & 15 & 46.8 & 25 & 78.1 & & \\
\hline Jumlah & 17 & 53.1 & 15 & 46.9 & 32 & 100 & & \\
\hline
\end{tabular}

Tabel 4. Distribusi Hubungan Fasilitas IRD dengan Waktu Tanggap Penanganan Pasien Cedera Kepala $(n=32)$ 
Hasil penelitian tersebut diatas berbanding lurus dengan penelitian sebelumnya yang dilakukan oleh Virgin (2000), yang mengemukakan bahwa fasilitas menjadi salah satu faktor yang berpengaruh terhadap waktu tanggap penanganan pasien, hal ini juga sejalan dengan penelitian yang dilakukan oleh Sabriyati (2012) yang meneliti faktorfaktor yang berhubungan dengan ketepatan waktu tanggap penanganan pada kasus respon time I di instalasi gawat darurat bedah dan non bedah di RSUP. Wahidin Sudirohusodo Makassar, terhadap 56 orang responden dan mengemukakan hasil bahwa fasilitas mempunyai hubungan yang erat dengan waktu tanggap penanganan pasien.

Hasil penelitian menunjukkan bahwa sebanyak $(46,8 \%)$ atau kurang dari setengah jumlah responden memiliki waktu tanggap yang baik saat menangani pasien cedera kepala dengan fasilitas tersedia, hal ini terjadi karena responden sudah berpengalaman dalam menangani pasien cedera kepala beberapa dari mereka telah mengikuti berbagai pelatihan kegawatdaruratan serta telah lama bekerja di IRD. Akan tetapi sebanyak sebanyak (31,3\%) responden memiliki waktu tanggap yang buruk justru saat fasilitas sudah tersedia, hal ini karena perawat terlalu lamban dalam memberikan tindakan awal terhadap pasien cedera kepala karena dianggap pasien masih dalam kondisi baik dan tidak memerlukan penanganan segera, sehingga perawat lebih mementingkan pasien lain dibandingkan pasien yang sudah masuk ke ruang tindakan bedah, Selain itu terdapat $(21,9 \%)$ atau kurang dari seperempat jumlah responden memiliki waktu tanggap yang buruk saat fasilitas tidak tersedia, ini disebabkan karena responden berusaha mencari alat dan bahan yang dibutuhkan untuk menangani pasien cedera kepala yang tidak tersedia di ruang tindakan saat pasien ditangani dan sebagian dari mereka menunggu instruksi dari dokter jaga IRD serta senior yang bertanggung jawab terhadap pasien bedah sehingga menyebabkan waktu tanggap menjadi buruk atau lebih dari 5 menit.

Fasilitas dianggap tidak memadai apabila saat pasien tersebut memerlukan suatu fasilitas namun fasilitas tersebut tidak bisa digunakan, baik karena tidak tersedia di ruangan IRD, digunakan oleh pasien lain atau ada tapi tersedia di ruangan lain misalnya di apotik atau ruang perawatan. Peneliti mengobservasi saat pasien ditangani dan menemukan beberapa fasilitas yang tidak tersedia saat pasien ditangani dan memerlukan fasilitas tersebut, misalnya saat menangani pasien cedera kepala berat yang memerlukan suction karena banyaknya darah yang keluar dari hidung dan mulut pasien, namun suction yang tersedia hanya 1 buah di ruang IRD.

Hal lain yang sering terjadi pada saat perawat menangani pasien cedera kepala berat dengan GCS $\leq 8$ yaitu tidak tersedianya alat intubasi di ruang IRD, sehingga dokter dan perawat yang akan melakukan pemasangan harus meresepkan terlebih dahulu lalu keluarga pasien akan segera ke apotik untuk menebus alat intubasi tersebut, sehingga ketidaktersediaan fasilitas ini mempengaruhi kinerja dan ketepatan waktu tanggap penanganan pasien, saat penelitian juga sering ditemukan ketidaktersediaan servical collar di ruangan sebab jumlahnya yang terbatas dan saat dibutuhkan dan persediaan telah digunakan untuk pasien lain, maka perawat akan berusaha mencari kardus kosong yang kemudian dimodifikasi menjadi servical collar untuk menyangga leher pasien yang dicurigai mengalami cedera servikal. Ketidaktersediaan atau tidak memadainya fasilitas tersebut tidak hanya akan mempengaruhi ketepatan waktu tanggap tetapi akan berdampak pada buruknya manajemen penanganan pasien diruangan tersebut.

Dari hasil penelitian ditemukan bahwa hasil uji statistik diperoleh nilai 
$\mathrm{p}=0,006$ yang menunjukkan bahwa ada hubungan tingkat kegawatan pasien dengan waktu tanggap penanganan cedera kepala, kemudian diperoleh nilai $P h i=0,548$

yang berarti bahwa tingkat kegawatan pasien memiliki kekuatan hubungan yang kuat dengan waktu tanggap penanganan pasien cedera kepala, hal ini berarti bahwa semakin berat tingkat kegawatan pasien maka semakin tanggap penanganan yang diberikan karena akan berpengaruh terhadap keselamatan jiwa pasien.

\begin{tabular}{ccccccccc}
\hline \multirow{2}{*}{$\begin{array}{c}\text { Tingkat } \\
\text { Kegawatan } \\
\text { Pasien }\end{array}$} & \multicolumn{9}{c}{ Waktu Tanggap Cedera Kepala } & & \multirow{2}{*}{ Total } & P Value & Phi \\
\cline { 2 - 6 } & $\mathrm{n}$ & $\%$ & $\mathrm{n}$ & $\%$ & $\mathrm{n}$ & $\%$ & & \\
\hline Ringan & 10 & 31.2 & 1 & 3.1 & 11 & 34.4 & \multirow{2}{*}{0.006} & 0.548 \\
\hline Berat & 7 & 21.9 & 14 & 43.7 & 21 & 65.6 & & \\
\hline Jumlah & 17 & 53.1 & 15 & 46.9 & 32 & 100 & & \\
\hline
\end{tabular}

Tabe1 5. Distribusi Hubungan Tingkat Kegawatan Pasien dengan Waktu Tanggap Penanganan Pasien Cedera Kepala (n=32)

Danille (2011) mengemukakan bahwa pasien yang datang meminta pertolongan di ruang gawat darurat, harus ditangani sesegera mungkin sesaat setelah mereka berada di ruang tersebut, karena hal ini akan berpengaruh terhadap keselamatan pasien kedepannya sekaligus menghindari terjadinya kecacatan pada pasien cedera kepala baik dari segi fisik maupun neurologis, akibat lambannya penanganan yang diberikan oleh tenaga kesehatan khususnya oleh dokter dan perawat yang bertugas saat pasien tersebut masuk ke IRD. Pasien cedera kepala yang masuk ke IRD harus dengan cepat dilakukan pemeriksaan dan menentukan tingkat kegawatannya baik dengan menggunakan Glasgow Coma Scale (GCS) ataupun Revised Trauma Score (RTS) untuk membedakan pasien dengan prognosis baik ataupun buruk. (Fedakar, 2007).

Penelitian yang dilakukan tersebut sejalan dengan hasil penelitian yang dilakukan sebelumya oleh Jus (2008) yang menunjukkan bahwa terdapat hubungan antara tingkat kegawatan pasien dengan waktu tanggap penanganan pasien cedera kepala, akan tetapi penelitian tersebut berbanding terbalik dengan penelitian yang dilakukan oleh Wahyudi (2012) yang meneliti tentang faktor resiko yang berhubungan dengan tingkat keparahan cedera kepala di RSUD. Karanganyar dengan jumlah sampel 145 orang dan mengemukakan tidak ada hubungan antara tingkat kegawatan pasien dengan waktu tanggap penanganan pasien cedera kepala, hal ini disebabkan karena saat pengambilan data tentang lamanya mendapatkan pertolongan pertama hanya berdasarkan perkiraan waktu atau catatan kepolisian dan tidak dilakukan berdasarkan hasil pengukuran jam sebenarnya.

Hasil penelitian menunjukkan bahwa sebanyak $(43,7 \%)$ responden yang menangani pasien cedera kepala berat telah memiliki waktu tanggap baik, hal ini dikarenakan mereka telah lama bekerja di IRD dan telah mengikuti banyak pelatihan kegawatdaruratan. Akan tetapi terdapat $(21,9 \%)$ responden yang menangani pasien cedera kepala berat memiliki waktu tanggap yang buruk, disebabkan karena kurangnya pengalaman dalam menangani pasien cedera kepala dengan tingkat kegawatan berat, fasilitas yang perawat butuhkan tidak tersedia serta mereka juga adalah perawat yang baru ditempatkan di IRD.

Responden yang menangani pasien cedera kepala ringan, 
sebanyak $(31,2 \%)$ atau lebih dari seperempat jumlah responden memiliki waktu tanggap yang buruk, hal ini disebabkan karena responden tidak segera menangani pasien cedera kepala ringan yang ada sesaat setelah mereka tiba di pintu IRD akan tetapi mereka sibuk memberikan pertanyaan seputar keluhan dan kejadian yang terjadi sampai pasien dibawa masuk ke IRD, setelah itu barulah perawat melakukan tindakan awal misalnya membersihkan luka pasien.

Terdapat $(3,1 \%)$ responden yang menangani pasien cedera kepala dengan tingkat kegawataan ringan dan memiliki waktu tanggap yang baik, hal ini terjadi karena responden langsung memberikan penanganan awal terhadap pasien sesaat setelah mereka tiba di pintu IRD, selain itu responden tersebut telah lama bekerja di IRD dan pernah mengikuti pelatihan kegawatdaruratan, sehingga lebih tanggap dalam menangani pasien cedera kepala meskipun dengan tingkat kegawatan ringan.

Faktor yang Paling Berhubungan dengan Waktu Tanggap Penanganan Pasien Cedera Kepala. Dari analisis regresi logistik didapatkan variabel yang paling berhubungan dengan waktu tanggap adalah lama kerja, fasilitas IRD dan tingkat kegawatan pasien, berdasarkan tabel di atas variabel independen yang paling berhubungan dengan waktu tanggap penanganan pasien cedera kepala adalah fasilitas IRD dengan nilai OR $=6,945$ yang artinya fasilitas memiliki kecenderungan 6,945 atau 7 kali lebih besar mempengaruhi waktu tanggap dibanding variabel lain yang memiliki hubungan dengan waktu tanggap

\begin{tabular}{lcccc}
\hline \multirow{2}{*}{ Variabel } & \multirow{2}{*}{ Sig } & \multirow{2}{*}{ Exp (B) } & \multicolumn{2}{c}{ 95\% C.I. for exp (B) } \\
\cline { 4 - 5 } & & & Lower & Upper \\
\hline Lama kerja & 0.998 & 3.305 & 0.000 & - \\
\hline Fasilitas & 0.998 & 6.945 & 0.000 & - \\
\hline Tingkat kegawatan & 0.997 & 3.844 & 0.000 & - \\
\hline Constant & 1.000 & 0.187 & & \\
\hline
\end{tabular}

Tabel 6. Distribusi Variabel yang Paling Berhubungandengan waktu tanggap penanganan pasien cedera kepala

Hasil penelitian ini sesuai dengan teori yang dikemukakan oleh Pronowo (2006) bahwa instalasi rawat darurat sebagai garda terdepan dalam melayani pasien seharusnya dilengkapi dengan fasilitas yang memadai, ketersediaan fasilitas akan berdampak pada baiknya pelayanan yang diberikan oleh tenaga kesehataan yang bertugas di IRD khususnya perawat yang bersentuhan langsung dengan pasien, dengan catatan perawat tersebut mampu menggunakan fasilitas tersebut dengan baik sesuai fungsinya.

Tersedianya fasilitas di ruang IRD saat perawat malakukan penanganan pada pasien cedera kepala akan berpengaruh terhadap ketepatan waktu tanggap penanganan pasien. Ketidaktersediaan fasilitas atau tidak memadainya fasilitas di ruang IRD akan mempengaruhi buruknya waktu tanggap penanganan dan berdampak dan berdampak pada keselamatan pasien. Segala fasilitas yang harus tersedia di IRD berdasarkan standar prosedur operasional (SOP) rumah sakit harus betul-betul tersedia dengan jumlah yang memadai dengan memperkirakan jumlah kunjungan pasien di IRD tersebut, sehingga dalam menangani pasien, fasilitas tidak lagi menjadi kendala sebab semua yang dibutuhkan tersedia lengkap dan bisa langsung dipergunakan kepada pasien yang membutuhkan.

\section{KESIMPULAN}

Hasil penelitian ini menyimpulkan bahwa ada hubungan tingkat Pendidikan Perawat dengan waktu 
tanggap penanganan pasien cedera kepala dengan nilai $p=0,006$. Ada hubungan lama kerja perawat dengan waktu tanggap penanganan pasien cedera kepala dengan nilai $\mathrm{p}=0,005$. Ada hubungan pelatihan kegawatdaruratan yang diikuti Perawat dengan waktu tanggap penanganan pasien cedera kepala dengan nilai $\mathrm{p}=0,001$. Ada hubungan fasilitas IRD dengan waktu tanggap penanganan pasien cedera kepala dengan nilai $\mathrm{p}=0,008$. Ada hubungan Tingkat kegawatan pasien dengan waktu tanggap penanganan pasien cedera kepala dengan nilai $\mathrm{p}=0,006$.

Hasil analisis regresi logistik didapatkan variabel yang paling berhubungan dengan waktu tanggap adalah fasilitas dengan nilai OR = 6,945 yang artinya fasilitas memiliki hubungan dengan waktu tanggap 6,9 atau 7 kali lebih kuat dibandingkan dengan variabel lain yang berhubungan dengan waktu tanggap.

\section{SARAN}

Diharapkan kepada pihak rumah sakit agar senantiasa melengkapi fasilitas dan meningkatkan kualitas sumber daya manusia (SDM) dari tenaga perawat dengan mengikutkan mereka pendidikan dan pelatihan secara bergilir, sesuai dengan kompetensi masing-masing khususnya yang bekerja di unit khusus seperti IRD, ICU dan sebagainya.

Bagi Peneliti Berikutnya diharapkan agar melakukan eksplorasi penelitian yang lebih luas terhadap faktor-faktor lain yang mempengaruhi waktu tanggap penanganan pasien cedera kepala dengan menggunakan metode penelitian kohort prospektif, agar dapat diketahui dampak dari waktu tanggap yang diberikan dan dilakukan dibeberapa rumah sakit lain dengan sampel yang lebih banyak.

\section{DAFTAR PUSTAKA}

Al-Mochdar, S. (2005). Studi Retrospektif Deskriptif Mengenai Beberapa Faktor yang Mempengaruhi Hasil Akhir Penderita
Epidural Hematoma di RSUPN Cipto Mangunkusumo periode 2001-2004. Tesis dipublikasikan. Jakarta: Program Pascasarjana Universitas Indonesia.

Anjaryani. (2009). Kepuasan Pasien Rawat Inap terhadap Pelayanan Perawat di RSUD Tugurejo Semarang. Skripsi tidak dipublikasikan. Semarang: Program Sarjana Kesehatan Masyarakat Universitas Diponegoro Semarang.

Arifin, M. (2013). Cedera kepala. Jakarta: Sagung Seto.

Awases, M. H. (2006). Factors affecting performance of professional nurses in Namibia. Journal of University of South Africa , p. 136-138.

Babu et al (2005). Extradural hematoma : An experience of 300 cases extradural. JK Science , 7 (4), p. 205-207.

Brain Injury Association of America. (2006). Cognitive rehabilitation: The evidence, funding and case for advocacy in brain injury. America: Brain Injury Association.

Bresler, M. J. (2006). Kedokteran darurat. Jakarta: EGC.

Danille et al. (2011). The incidence of traumatic brain injury in young people in the catachment area of the university hospital Rotterdam, the Netherlands . European Journal of Pediartric Neurology , p. 1-8.

Departemen Kesehatan Republik Indonesia. (2005). Pedoman perhitungan kebutuhan tenaga perawat di ruang gawat darurat. Jakarta: Departemen Kesehatan Republik Indonesia .

Fedakar, R. (2007). A comparison of life treatening injury concept in the Turkish penal code and trauma scoring systems. Ulus Trauma Acil Cerrahi Derg, p.192198.

Hafizurrachman, L. T. (2011). Beberapa faktor yang mempengaruhi kinerja perawat dalam menjalankan kebijakan keperawatan di rumah sakit umum daerah. Journal of Indonesian Medical Association , 61 (10), p. 387-393.

Hapsari, D.B. (2008). Pengaruh fasilitas kerja, disiplin kerja dan pengawasan terhadap produktivitas kerja karyawan. Jurnal Universitas Muhammadiyah, p. 3-4.

Haryatun.N, S. (2008). Perbedaan waktu tanggap tindakan keperawatan pasien cedera kepala kategori $I-V$ di instalasi gawat darurat RSUD. DR. Moewardi. Berita Ilmu Keperawatan , 1 (2), p. 69-74.

Instalasi Rekam Medik RSUD.Prof. DR.H.M.Anwar Makkatutu. (2013). Data pasien cedera kepala tahun 2011-2012. Bantaeng: Instalasi Rekam Medik RSUD. Prof.DR.H.M.Anwar Makkatutu.

Irawan, H. (2010). Perbandingan Glasgow coma scale dan revised trauma score dalam memprediksi disabilitas pasien trauma kepala di rumah sakit Atma jaya. Jurnal Kedokteran Indonesia , 60, p. 437-442. 
Iskandar, J. (2004). Cedera kepala. Jakarta: PT. Bhuana Ilmu Populer.

Jus, E. (2008). Factors influencing lenght of stay in the emergency departement in a private hospital in north Jakarta. Journal of Universa Medicina , 27 (4), p. 165-173.

Kasmarani, M. K. (2012). Pengaruh beban kerja fisik dan mental terhadap stres kerja pada perawat di instalasi gawat darurat RSUD Cianjur. Jurnal Kesehatan Masyarakat , 1 (2), p. 767-776.

Keputusan menteri Kesehatan Republik Indonesia. (2009). Standar instalasi gawat darurat (IGD) rumah sakit. Jakarta: Menteri Kesehatan Republik Indonesia.

Krisanty.P, M. W. (2009). Asuhan Keperawatan gawat darurat. Jakarta: Trans Info media. Lingsma.H.F. (2010). Early prognosis in traumatic brain injury : from prophecies to predictors. Lancet Neurol , 9, p. 543554.

Maas.A. (2008). Moderate and severe traumatic brain injury in adults. Lancet Neurol , 7, p. $728-741$.

McLean.B, Z. (2007). Fundamental critical care support. Journal of Trauma Critical Care , p. 8-16.

Meltzer, L. S. (2004). Critical care nurse's perceptions of futile care and its effect on burnout. American Association of Critical Care Journal , p. 1-9.

Muttaqin, A. (2008). Asuhan keperawatan klien dengan gangguan sistem persarafan. Jakarta: Salemba Medika.

Notoatmojo, S. (2010). Metodologi Penelitian kesehatan. Jakarta: Rinika Cipta.

Nursalam. (2013). Manajemen keperawatan : Aplikasi dalam praktik keperawatan profesional. Jakarta: Salemba Medika.

Ozkan.U, K. O. (2007). Analyzing extradural haematomas : A retrospective clinical investigation. Dicle Tip Dergisi , 34 (1), p. 14-19.

Pallant, J. (2011). SPSS SURVIVAL MANUAL, A Step by step guide data analysis using SPSS 4th edition. Australia : Allent \& Unwin.

Pranowo, K.T. (2006). Pengaruh Waktu Penatalaksanaan Kegawatdaruratan Medis terhadap Mutu Pelayanan di Instalasi Gawat darurat RSUD Bantul . Skripsi tidak dipublikasikan. Yogyakarta: Program Sarjana Kesehatan masyarakat Universitas Muhammadiyah.

Pratiwi.A, W. (2008). Hubungan beban kerja dengan waktu tanggap perawat gawat darurat menurut persepsi pasien di instalasi gawat darurat RSU Pandan Arang Boyolali. Berita Ilmu Keperawatan , 1 (3), p. 125-130.

Purwadianto.A, S. (2013). Pedoman penatalaksanaan praktis kedaruratan medis; disertai contoh kasus klinis. Jakarta: Binarupa Aksara.

Puvanachandra.P, Hayder. A. (2009). The burden of traumatic brain injury in asia: A call for research. Journal of Neurological Science , 4 (1), p. 27-32.

Sabriaty.NI, I. G. (2012). Factors Related To The Accurary of Response Time in Case Handling At The 1st Response Time in Surgery and Non Surgery Emergency Room of DR. Wahidin Sudirohusodo General Hospital. Tesis tidak dipublikasi. Makassar: Program Pasca Sarjana Biomedik, Emergency and Disaster Management Universitas Hasanuddin Makassar.

Sadewo.W. (2005). Epidural hematoma : studi prospektif deskriptif analitik mengenai hubungan klinik radiologis dan operatif terhadap outcome penderita di bagian bedah saraf RSUPN. Cipto Mangunkusumo . Tesis dipublikasikan. Jakarta: Program PPDS Ilmu Bedah saraf Universitas Indonesia.

Sarangi.L, P. P. (2009). Study on Epidemiological factors associated with road traffic accidents presenting to the casualty of a private hospital in Bhubaneswar. Journal of Community Medicine , 5 (2), p. 1-10.

Satyanegara. (2010). Ilmu bedah saraf. Jakarta: Gramedia.

Shiroma, E.J. (2010). Prevalence of traumatic brain injury in an offonder population. Head Trauma Rehabil , 27, p. 1-10.

Siagian, SP. (2009). Sistem informasi manajemen. Jakarta: Bumi Aksara.

Simamora, R. H. (2009). Pendidikan dalam keperawatan. Jakarta: EGC.

Soertidewi.L, M. S. (2006). Konsensus nasional penanganan trauma kapitis dan trauma spinal. Jakarta: Perdossi.

Sugiyono. (2012). Metode penelitian kuantitatif kualitatif dan R\&D. Bandung: Alfabeta.

Sumijatun. (2009). Manajemen keperawatan; Konsep dasar dan aplikasi pengambilan keputusan klinis. Jakarta: Trans Info Media.

Sutcliffe, A.J. (2007). Traumatic brain injury : Critical care management. Journal of Trauma Critical Care , p. 201-219.

Virgin, F. (2000). Analisis proses pelayanan terhadap pasien yang akan menjalani operasi cito di instalasi rawat darurat RSUP Fatmawati . Tesis tidak dipublikasi. Jakarta: Program Studi Kajian Administrasi Rumah Sakit Program Pasca sarjana FKM UI.

Wahyudi,S. (2012). Faktor resiko yang berhubungan dengan tingkat keparahan cedera kepala (studi kasus pada korban kecelakaan lalu lintas pengendara sepeda motor di RSUD Karanganyar). Unnes Journal Of Public Health, p. 41-48.

Wilde, E. (2009). Do emergency medical system response time matter for health outcomes. New York: Colombia University.

Yayasan Ambulans Gawat Darurat 118. (2009). Basic trauma life support \& basic cardiac 
Indonesian Contemporary Nursing Journal, 2(1), 1-12

life support. Jakarta: Yayasan Ambulans Gawat Darurat 118

Yoon. P, S. I. (2003). Analysis of factors influencing length of stay in the emergency department. Can J Emergency Med, 5 (3), p. $155-161$

Yulius.T. (2010). Acid-base disorder due to hypernatremia in head injury. Journal of Anastesia and Critical Care , 28 (3), p. 34-44. 